\title{
HIPPOCRATES AND SOCRATES: PROFESSIONAL OBLIGATIONS TO EDUCATE THE NEXT GENERATION
}

\author{
Deborah Jones Merritt*
}

Do professionals have an ethical obligation to educate new members of their profession? The ancient Hippocratic oath recognized such a commitment, requiring all doctors "to give a share of precepts and oral instruction and all the other learning ... to pupils who have signed the covenant." 1 Contemporary theories of professionalism point to the same result, identifying intergenerational education as an essential feature of professional status. ${ }^{2}$ Moral theory and economic policy underscore this outcome: in return for the exclusive right to practice a profession, established members of the profession must agree to share their knowledge, skills, and other expertise with newcomers. ${ }^{3}$

Sadly, the rules of professional conduct governing lawyers do not mention this duty to educate. 4 Equally unfortunate, mounting evidence suggests that neither law schools nor the practicing bar are fulfilling their ethical obligation to educate new members of the profession. ${ }^{5}$ This Article explores that ethical gap and considers ways law schools could restore their ethical commitment to educate new members of the bar. To provide background, Part I of the Article examines the historical, social, moral, and economic roots of a professional obligation to educate. Part II analyzes the status of this obligation within the legal profession. Finally, Part III proposes six ways legal educators can advance our ethical commitment to educating new lawyers.

\section{Foundations}

What is a profession? Scholars have long struggled to answer that question. Full examination of that scholarship is beyond the scope of this Article, but I offer below some representative

* John Deaver Drinko/Baker \& Hostetler Chair in Law, Moritz College of Law, The Ohio State University.

1. Ludwig Edelstein, The Hippocratic OATH 3 (Ludwig Edelstein trans., 1943); see also infra Part I.A.

2. See infra Part I.B.

3. See infra Parts I.C, I.D.

4. See infra Part II.A.

5. See infra Part II.B. 
perspectives drawn from history, the sociology of the professions, moral theory, and economic principles. Notably, all of these sources agree that a duty to educate new members lies at the heart of professional status.

\section{A. The Hippocratic Oath}

In Western cultures, the Hippocratic oath is one of the oldest and most enduring images of professional identity. ${ }^{6}$ The ancient Greek physician Hippocrates-or perhaps one of his studentsauthored the oath to summarize a doctor's ethical duties to patients, colleagues, and the community. ${ }^{7}$ Although popular discussions of the Hippocratic oath focus on the doctor-patient relationship, the oath also specifies the doctor's relationship to the professional community. In the oath's quaint terms, a doctor swears:

To hold him who has taught me this art as equal to my parents and to live my life in partnership with him, and if he is in need of money to give him a share of mine, and to regard his offspring as equal to my brothers in male lineage and to teach them this art-if they desire to learn it-without fee and covenant; to give a share of precepts and oral instruction and all the other learning to my sons and to the sons of him who has instructed me and to pupils who have signed the covenant and have taken an oath according to the medical law, but to no one else. ${ }^{8}$

This covenant includes four interwoven components. First, the new doctor affirms that the medical profession is a tightly bound community with internal obligations as strong as those that bind family. Second, building on this familial metaphor, the doctor promises to uphold the community's intergenerational duties, honoring predecessors and teaching successors. Third, the oath taker acknowledges that these duties may require financial sacrifice. The new doctor swears to support a mentor in financial need and to teach the mentor's offspring "without fee and covenant."9 Finally, the doctor vows to limit her teaching to "pupils who have signed the covenant and taken an oath."10 This promise draws a sharp line between the medical community and all others.

6. See, e.g., V.I. Bakshtanovskii \& Iu. V. Sogomonov, Professional Ethics: Sociological Perspectives, 46 SOC. RES. 75, 75 (2007) ("Just about the first image that comes to our mind in connection with an expression like "professional ethics (morality)' is the Hippocratic oath."). For a recent discussion of the oath's history, see Lisa R. Hasday, The Hippocratic Oath as Literary Text: A Dialogue Between Law and Medicine, 2 Yale J. Health Pol'Y L. \& Ethics 299, 301-05 (2002).

7. Hasday, supra note 6 , at 301 .

8. EDELSTEIN, supra note 1 , at 3 .

9. Id.

10. Id. 
Modern versions of the Hippocratic oath describe the doctor's obligation to the professional community less effusively, but most include some reference to educating other members of the profession. One of the most popular updates, created by Dr. Louis Lasagna in 1964, includes this promise: "I will respect the hard-won scientific gains of those physicians in whose steps I walk, and gladly share such knowledge as is mine with those who are to follow." 11 A more recent iteration, produced by the Weill Cornell Medical College, requires graduates to make the following vow: "That just as I have learned from those who preceded me, so will I instruct those who follow me in the science and the art of medicine."12

After reviewing these and other oaths, a contemporary medical expert concluded that one of the "cardinal points" of medical oaths is "[a] statement that teaching those who come after us as well as our colleagues and learning from them ... shall have an equal standing as does patient care today."13 The American Medical Association's concise Principles of Medical Ethics includes the same commitment. One of the nine principles declares: "A physician shall continue to study, apply, and advance scientific knowledge, maintain a commitment to medical education, [and] make relevant information available to ... colleagues...." 14 Both the Hippocratic oath and modern medical codes thus acknowledge the essential role of intergenerational education in a profession.

\section{B. Sociology of the Professions}

A subfield of sociology examines the characteristics and social status of professionals. ${ }^{15}$ Sociologists in this field agree that professionals demonstrate at least three characteristics: they apply

11. Harold C. Sox, The Ethical Foundations of Professionalism: A Sociological History, 131 CHEST 1532, 1540 (2007) (reprinting the Lasagna oath as an appendix). Lasagna wrote the oath for students graduating from Tufts University's School of Medicine. It spread from there to numerous other schools.

12. Erich H. Loewy, Oaths for Physicians-Necessary Protection or Elaborate Hoax?, MEDSCAPE (2007), http://www.medscape.com/viewarticle 1550118_3. The Cornell oath also retains the concept of succoring other members of the profession: "I will honor the Profession of medicine, be just and generous to its members, and help sustain them in their service to humanity." Id.

13. Id.

14. Id. Osteopaths recognize a similar commitment in their version of the Hippocratic oath. That oath currently includes these words: "I will look with respect and esteem upon all those who have taught me my art. To my college I will be loyal and strive always for its best interests and for the interests of the students who will come after me." Osteopathic Oath, AM. OsteopaTHIC Ass'N, http://www.osteopathic.org/inside-aoa/about/leadership/Pages/osteopathicoath .aspx (last visited Mar. 16, 2016).

15. See generally Julia Evetts, Short Note: The Sociology of Professional Groups, 54 CuRRENT Soc. 133 (2006). 
specialized bodies of knowledge, maintain complex educational systems to convey that knowledge, and impart ethical codes as part of that education. ${ }^{16}$ In the words of Andrew Abbott, a leading scholar in the field, professions are "organized bodies of experts who appl[y] esoteric knowledge to particular cases. They ha[ve] elaborate systems of instruction and training, together with entry by examination and other formal prerequisites. They normally possess [ and enforce[ a code of ethics or behavior."17

This consensus highlights the centrality of education within a professional community. Complex "systems of instruction and training" are not just common to all professions, they are essential to capture the profession's specialized knowledge, transmit that knowledge to newcomers, and inform the profession's ethical code. Participation in an educational community also allows a profession to maintain a strong boundary between its members and outsiders. Without a commitment to education, a profession risks dissipation of its knowledge, diminishment of its membership, and competition from nonprofessionals.

Building on these insights, Howard Gardner and Lee Shulman proposed in a prominent symposium that all professions share six "commonplaces":

a commitment to serve in the interests of clients in particular and the welfare of society in general; a body of theory or special knowledge with its own principles of growth and reorganization; a specialized set of professional skills, practices, and performances unique to the profession; the developed capacity to render judgments with integrity under conditions of both technical and ethical uncertainty; an organized approach to learning from experience both individually and collectively and, thus, of growing new knowledge from the contexts of practice; and the development of a professional community responsible for the oversight and

16. See Howard Gardner \& Lee S. Shulman, The Professions in America Today: Crucial but Fragile, DeDALUS, Summer 2005, at 13, 14.

17. Andrew AbbotT, The System of Professions 4 (1988). Although Abbott and other sociologists recognize these common characteristics of professions, most contemporary sociologists eschew any attempt to draw a firm line between professions and other occupations. See generally Evetts, supra note 15 , at 134 (summarizing consensus on this point). Some sociologists even argue that professions have no intrinsic characteristics. Instead, they maintain that professions are occupational groups that succeed in using the political process to achieve unusual power, such as self-regulation. See, e.g., James W. Begun, Economic and Sociological Approaches to Professionalism, 13 WORK \& OCCUPATIONS 113 (1986) (describing opposing theories of professions). Despite these disputes, there is broad agreement that the historic professions of law and medicine possess the characteristics noted in this Article. 
monitoring of quality in both practice and professional education. ${ }^{18}$

Professionals often focus on the first of these features, stressing their duty to put clients and society ahead of self-interest. That obligation is critical for professionals, but the other elements of Gardner and Shulman's framework contribute equally to our understanding of professional work. As Gardner and Shulman recognize, professionals must develop both a "body of theory or specialized knowledge" and "a specialized set of professional skills, practices, and performances unique to [their] profession." 19 In addition, they must develop a "capacity to render judgments with integrity under conditions of both technical and ethical uncertainty."20 All of these elements, in turn, require an "organized approach to learning" and "the development of a professional community responsible for the oversight and monitoring of quality in both practice and professional education."21

The cognitive demands of professional practice require a highly developed educational community. This community nourishes both newcomers and established members. Newcomers learn the profession's established theory and practices, while established members hone their performance. Learning-centered collaborations, according to Gardner and Shulman, define an occupation as a profession.

\section{Moral Theory}

Moral theory also supports a profession's duty to educate. The legal philosopher Jeremy Waldron, for example, has described a set of rights that he calls "responsibility-rights."22 These are rights that depend on the exercise of a designated responsibility. The rights do not merely call for responsible behavior; they arise to facilitate responsibilities. The right, therefore, cannot exist without exercise of the responsibility. ${ }^{23}$

Waldron identifies parental rights as a prime example of responsibility-rights. ${ }^{24}$ Parents have vast power to control the lives

18. Gardner \& Shulman, supra note 16, at 14. Gardner is the John H. and Elisabeth A. Hobbs Professor of Cognition and Education at the Harvard Graduate School of Education. Shulman is the Charles E. Ducommun Professor of Education Emeritus at Stanford University; he is a past president of both the Carnegie Foundation for the Advancement of Teaching and the American Educational Research Association.

19. Id. The latter skills, Gardner and Shulman conclude, constitute "the defining characteristic" of each profession. Id. at 15.

20. Id. at 14 .

21. Id.

22. Jeremy Waldron, Dignity, Rights, and Responsibilities, 43 ARIz. ST. L.J. 1107,1116 (2011).

23. Id. at 1114 .

24. Id. at 1114-15. 
of their children, but their rights exist only to facilitate their responsibility to care for the child. Parents' rights do not allow them to act capriciously or maliciously; parents can exercise their parental rights only to further responsible care. ${ }^{25}$

As I have argued elsewhere, many professions reflect a similar pattern of rights and responsibilities. ${ }^{26}$ These professions, including law, receive two valuable rights from society: an exclusive right to deliver services associated with the profession and the right of selfgovernment. These rights, like parental rights, exist to facilitate responsibilities. Society does not grant autonomy to lawyers because it loves lawyers and wants to give them as much power as possible. Instead, lawyers have persuaded society that an autonomous profession will deliver the best results to clients and other members of society. Lawyers do not just have a right to practice law and prevent others from doing so; they have a responsibility to operate their profession in a way that satisfies society's need for legal services. ${ }^{27}$

As part of that responsibility-right, lawyers surely have an obligation to educate new members of their profession. If lawyers do not perform that role, then who will? Lawyers claim exclusive rights to practice law and to admit new members to the profession. If they fail to educate those members, no one else can fill the gap. The rights to exclusivity and autonomy imply a responsibility to maintain an ongoing, educated profession.

\section{Economic Principles}

Economic principles confirm that professionals assume an ethical duty to educate new members of their profession-at least when the profession enforces an exclusive right to provide services to clients. Exclusivity raises prices by foreclosing competition, an effect economists have documented in the market for legal services. ${ }^{28}$ Regulators permit professionals to collect that premium because they assume that a restricted profession will deliver more

25. Id. at $1115-16$.

26. Deborah Jones Merritt \& Daniel C. Merritt, Responsibility-Rights in the Legal Profession, 43 ARIz. ST. L.J. 1257, 1257 (2011).

27. Id. at 1262-64; see also James C. Gaa, A Game-Theoretic Analysis of Professional Rights and Responsibilities, 9 J. Bus. ETHICs 159, 159 (1990) ("The basic agreement between a profession and society concerns the degree to which the profession is allowed by society to govern its own affairs, in exchange for a commitment to act in 'the public interest.").

28. See Clifford Winston et al., Ftrst Thing We Do, Let's Deregulate All the LAWYERS 55-56 (2011); Richard L. Abel, Why Does the ABA Promulgate Ethical Rules?, 59 TEx. L. REv. 639, 653-54 (1981); Benjamin H. Barton, Do Judges Systematically Favor the Interests of the Legal Profession?, 59 ALA. L. REv. 453, 461-63 (2008); Gillian K. Hadfield, Legal Barriers to Innovation: The Growing Economic Cost of Professional Control Over Corporate Legal Markets, 60 STAN. L. REV. 1689, 1694 \& n.20 (2008). 
competent, responsive, and efficient services than one that competes in the open market. ${ }^{29}$

This framework, however, rests on the assumption that professions will invest some of their market premium in assuring the competence of their members. If the profession does not invest in its members' expertise, why should society continue to grant the profession exclusive practice rights? Absent a professional commitment to ongoing education, the market might better determine appropriate competence levels and educational programs.

The duty to educate also combats a moral hazard that can arise among professionals: senior practitioners may hoard expertise in order to maintain their client base and premium income. Established practitioners may also tacitly support educational practices that give newcomers access to the profession without giving them the expertise that they need to compete with more senior colleagues. A recognized commitment to educate new members of the profession can constrain these antisocial practices.

\section{The Legal PROFEssion}

How has the legal profession responded to the educational duties described above? Unfortunately, as Subpart II.A demonstrates, our rules of professional conduct do not incorporate a duty to educate new lawyers. Furthermore, as I discuss in Subpart II.B, both legal educators and practitioners fall short in fulfilling the duties that their professional status implies.

\section{A. Rules of Professional Conduct}

The American Bar Association ("ABA") Model Rules of Professional Conduct, which inform professional responsibility rules in most states, do not recognize a duty to educate new lawyers. ${ }^{30}$ The preamble to those rules acknowledges that "[a]s a member of a learned profession, a lawyer should cultivate knowledge of the law beyond its use for clients, employ that knowledge in reform of the law and work to strengthen legal education." 31 That language, consistent with the authorities discussed above, recognizes the centrality of education to a profession like law. The rules, however, fall short of further articulating each professional's duty to contribute to that education. Only two rules, Rule 1.1 and Rule 5.1, even approach the topic of education.

29. Begun, supra note 17 , at 121.

30. Model RUles of Prof'L Conduct (AM. BAR Ass'N 2015). Most states have adopted rules quite similar to that model code. State Adoption of the ABA Model Rules of Professional Conduct, AM. BAR ASS'N, http://www.americanbar.org/groups/professional_responsibility/publications /model_rules_of_professional_conduct/alpha_list_state_adopting_model _rules.html (last visited Mar. 14, 2016).

31. MODEL RULES OF PROF'L CONDUCT pmbl. 
Rule 1.1 requires each lawyer to "provide competent representation to a client," but it does not oblige the profession to create that competence. ${ }^{32}$ On the contrary, the rules treat individual lawyers as autonomous actors responsible for their own competence. A comment to Rule 1.1, for example, directs that "[t]o maintain the requisite knowledge and skill, a lawyer should keep abreast of changes in the law and its practice." 33 The rule does not suggest that the profession has an obligation to maintain educational avenues to promote that competence.

Other comments to Rule 1.1, in fact, discourage lawyers from forming the type of professional relationships that might foster mentoring and collegial education. In theory, a new lawyer could develop the expertise to represent a client in a novel field "through the association of a lawyer of established competence in the field in question." 34 Comments 6 and 7, however, warn that these associations can generate problems with regard to client confidentiality, allocation of decision-making power, fee splitting, and unauthorized practice. ${ }^{35}$ The rule, in sum, provides little support for an obligation to educate other professionals.

Rule 5.1(b) treads a little closer to that concept by declaring that "[a] lawyer having direct supervisory authority over another lawyer shall make reasonable efforts to ensure that the other lawyer conforms to the Rules of Professional Conduct." 36 Competence is one of those rules, so a few courts have interpreted Rule 5.1 to require supervising lawyers to ensure that their junior lawyers are capable of handling the work assigned to them. ${ }^{37}$ Even that interpretation,

32. Id. r. 1.1.

33. Id. r. $1.1 \mathrm{cmt}$.; see also id. pmbl. ("A lawyer should strive to attain the highest level of skill, to improve the law and the legal profession and to exemplify the legal profession's ideals of public service.").

34. Id. r. $1.1 \mathrm{cmt}$. ("Competent representation can also be provided through the association of a lawyer of established competence in the field in question.").

35. Id. r. $1.1 \mathrm{~cm}$ ts. $6-7$.

36. Id. r. 5.1(b); see also id. r. 5.1(a) (imposing a similar obligation on law firm partners and others with "comparable managerial authority in a law firm" to "make reasonable efforts to ensure that the firm has in effect measures giving reasonable assurance that all lawyers in the firm conform to the Rules of Professional Conduct").

37. See, e.g., In re Bradley, 495 B.R. 747, 794 (Bankr. S.D. Tex. 2013) (stating that the court "may, and will impose sanctions against" a law firm for failing to "adequately train and supervise" newer attorneys); Att'y Grievance Comm'n of Md. v. Kimmel, 955 A.2d 269, 286 (Md. 2008) (explaining that supervising attorneys have a duty in Maryland to make sure employees are not being assigned work beyond their skill level); Att'y Grievance Comm'n of Md. v. Ficker, 706 A.2d 1045, 1052 (Md. 1998) (calling it "wholly and inexcusably inappropriate" for a supervising attorney to hand off a case to a novice employee one day before trial); see also FDIC v. Nathan, 804 F. Supp. 888, 897-98 (S.D. Tex. 1992) (recognizing attorney's obligation "to supervise attorneys in his firm and to deter negligent and unethical conduct" in the context of a malpractice action). See generally Lucy Isaki, From Sink or Swim to the Apprenticeship: 
however, fails to impose a positive duty to educate new lawyers. Firms and supervisors can comply with Rule 5.1's standard by confining new lawyers to routine work rather than educating them for more sophisticated tasks.

State rules of professional conduct are similarly silent on any duty to educate new members of the legal profession; I have not found any state code recognizing that obligation. Despite the history and theory of professional obligations described in Part I of this Article, the legal profession does not currently recognize a duty to educate its new members. ${ }^{38}$

\section{B. Contemporary Legal Education}

Although the legal profession's ethical code does not impose a duty to educate new members of the profession, the profession recognizes a practical need to provide that education. Without education for new lawyers, the profession would wither and society would find other ways to satisfy its need for legal services. Lawyers, like other professionals, have thus developed a system for educating new colleagues.

During the nineteenth and early twentieth centuries, the legal profession provided most of that education through apprenticeships. In the waning years of the nineteenth century, only one-fifth of practicing lawyers had attended any law school classes before starting their practice. ${ }^{39}$ Over the course of the twentieth century, however, lawyers steadily embraced academic preparation for practice. By 1984, more than ninety-nine percent of all new lawyers had completed a law school degree. ${ }^{40}$ In 2014, the most recent year for which figures are available, only 23 out of 51,180 successful bar examinees $(0.0005 \%)$ lacked a law degree. 41

Choices for Lawyer Training, 69 WASH. L. REV. 587, 589 (1994) (arguing that state bars should encourage firms to closely supervise new attorneys); Irwin D. Miller, Preventing Misconduct by Promoting the Ethics of Attorneys' Supervisory Duties, 70 NOTRE DAME L. REv. 259, 268 (1994) (advocating that supervisory attorneys should have a duty to prevent misconduct by newer attorneys).

38. Curiously, the ABA's Model Code of Professional Responsibility, which preceded the Model Rules of Professional Conduct, more explicitly recognized the profession's obligation to educate new members. Canon 1 declared that "A Lawyer Should Assist in Maintaining the Integrity and Competence of the Legal Profession." Model Code of Prof'L Responsibility Canon 1 (AM. BAR Ass'N 1980). EC 1-1 provided that "improving the competence of the bar to meet the highest standards is the ethical responsibility of every lawyer," and EC 1-2 observed that "the bar has a positive obligation to aid in the continued improvement of all phases of pre-admission and post-admission legal education." Id. EC 1-1, EC 1-2.

39. RICHARD L. ABEL, AMERICAN LAWYERS 41 (1989).

40. Id. at 42 .

41. See Nat'l Conference of Bar Exam'rs, 2014 Statistics, 84 BAR EXAMINER, March 2015, at 8, 13, http://www.ncbex.org/dmsdocument/164 (documenting that 48,524 successful exam takers had graduated from ABA-accredited law 
Despite the profession's reliance on academic education, practitioners frequently criticize law school programs. The critics fault law schools for being too academic, failing to introduce students to the realities of law practice, neglecting key lawyering skills, and dodging their duty to educate professionals. ${ }^{42}$ A growing chorus of voices suggests that law schools are not adequately training students for professional law practice. ${ }^{43}$

Practitioners, meanwhile, have reduced their commitment to educating new professionals. More than twenty years ago, Judge Harry Edwards observed, "as law firms have become increasingly materialistic ... we can no longer count on the law firms to be law schools." 44 The trend accelerated after the turn of the current century. As a former BigLaw partner recently lamented, a "dominant MBA-mentality ... forces firm leaders and everyone else to focus on short-term metrics.... [This] leaves little room (or time) for the personalized mentoring that turns good young lawyers into better older ones." 45

We have reached a dangerous point where both law schools and the bar are neglecting some of their responsibilities to educate new lawyers. To remedy this problem, educators and practitioners should renew their commitment to educating new members of the profession. Consistent with the theme of this Symposium, I will focus here on changes we could implement within the academy.

schools, 761 had graduated from nonaccredited schools, 1872 had graduated from foreign law schools, and 23 had prepared through law office practice).

42. Two of the most famous critiques from the bar and bench are SECTION of Legal Educ. \& Admissions to the BAR, AM. Bar Ass'N, Legal Education and Professional Development-An EduCATION ContinUUM (1992) (popularly known as the "MacCrate Report"), and Harry T. Edwards, The Growing Disjunction Between Legal Education and the Legal Profession, 91 MiCH. L. REv. 34 (1992). Widely read critiques have also arisen from legal educators and other scholars. See, e.g., RoY STUCKEY AND OTHERS, BEST PRACTICES FOR LEGAL EDUCATION (2007) (authored by Stuckey and other members of the Clinical Legal Education Association); William M. Sullivan ET AL., EduCATing LAWYERS: PREPARATION FOR THE PROFESSION OF LAW (2007) (sponsored by the Carnegie Foundation for the Advancement of Teaching). For an excellent recent review of these and other critiques, see Sarah Valentine, Flourish or Founder: The New Regulatory Regime in Legal Education, 44 J.L. \& EDUC. 473, 473 (2015) (arguing that law schools should embrace the proposed regulatory reforms proposed by critics in order to "recenter student learning").

43. See, e.g., Valentine, supra note 42 , at 474 ("[T] he criticism has grown more insistent in the past forty years and recently spilled over into the public sphere with newspaper articles decrying the failure of law schools to teach 'lawyering,' blogs warning students away from law school, and books touting one or more failures of the legal academy." (footnotes omitted)).

44. Edwards, supra note 42 , at 38.

45. Steven Harper, Where Have All the Mentors Gone?, AM. L. DaILY (July $23,2010,11: 36$ AM), http://amlawdaily.typepad.com/amlawdaily/2010/07 harpermentors.html. 
Other thinkers, I hope, will explore complementary reforms within the practicing bar.

\section{HONORING THE COMMITMENT}

How can law schools better honor their obligation to educate new members of the bar? I outline six steps-some with multiple facets-that law schools should take to honor that commitment. These steps are merely a start, but I believe they embody some of the most important reforms that law schools can make.

\section{A. Rethink Admissions and Scholarship Policies}

Legal education begins with student selection. A law school's admissions and scholarship policies affect both classroom learning 46 and the composition of the profession. ${ }^{47}$ There are at least two ways that schools could enhance their educational programs by adjusting these processes.

First, schools should stop making admissions and scholarship decisions with an eye toward influencing their status in the annual law school rankings published by U.S. News \& World Report. This commercial ranking scheme seduces law schools to choose students and award scholarships in a way that produces the highest possible median LSAT score for the entering class. ${ }^{48}$ Those strategies undermine our obligation to choose the students who will best succeed as committed, compassionate, and skillful lawyers.

46. See, e.g., Gregory Androushchak et al., Role of Peers in Student Academic Achievement in Exogenously Formed University Groups, 39 EDuc. STUD. 568 (2013); Anthony Lising Antonio et al., Effects of Racial Diversity on Complex Thinking in College Students, 15 PsYcH. SCI. 507 (2004) (demonstrating that heterogeneity in groups of college students promoted higher level problem solving compared to similar homogenous groups); Amanda L. Griffith \& Kevin N. Rask, Peer Effects in Higher Education: A Look at Heterogeneous Impacts, 39 ECON. EDUC. REV. 65 (2014) (showing that college students with lower SAT scores but high grades in high school often have a positive impact on the first-year performance of their roommates, and that male minority students receiving financial aid are most strongly affected by their peers); Sylvia Hurtado, The Next Generation of Diversity and Intergroup Relations Research, 61 J. Soc. IssuEs 595 (2005) ("Student interaction with diverse peers during college results in changes in student cognitive, social, and democratic outcomes by the second year of college.").

47. Law schools do not fully control bar admission; some graduates fail either the bar exam or character inquiries. It is almost impossible, however, to pass the bar exam without first obtaining a law degree. See supra note 41 and accompanying text. For that reason, law school admissions decisions have a profound impact on the shape of the profession.

48. See Brian Z. Tamanaha, Failing Law Schools 78, 85 (2012); Jeffrey Evans Stake, The Interplay Between Law School Rankings, Reputations, and Resource Allocation: Ways Rankings Mislead, 81 IND. L.J. 229, 233 (2006). 
An applicant's LSAT score clearly offers important information about the individual applicant. 49 Law schools, however, are giving those scores an unduly expansive role in both admissions and scholarship decisions. To maintain a favorable LSAT median, schools may admit applicants with the desired median score over applicants with slightly lower scores who show more overall potential.50 Equally worrisome, schools allot many of their scholarship dollars to applicants with LSAT scores at or above the school's median. ${ }^{51}$ These decisions, focused on rankings rather than student potential, do not serve the interests of society or future clients. As a result, they violate our commitment to delivering the best possible education to the profession.

The second flaw in law school admissions lies with schools that admit applicants with very weak academic credentials. As applications to law school have dwindled, some schools are admitting applicants with very low LSAT scores. ${ }^{52}$ These students face a high risk of failure, either in school or on the bar exam. ${ }^{53}$ The admission of these students during a time of depressed applications, and without evidence that schools have developed new programs for preparing at-risk students for bar and practice success, suggests that schools are placing their own budgetary interests above the interests of students, prospective clients, and society.

The ABA's accreditation standards for law schools provide that "[a] law school shall not admit an applicant who does not appear capable of satisfactorily completing its program of legal education and being admitted to the bar." 54 The ABA should enforce this standard, which reflects an appropriate commitment to responsible education.

\section{B. Make Legal Education Intentional}

Teachers at all levels have recognized the importance of making education intentional. ${ }^{55}$ An intentional educator identifies the goals

49. Stake, supra note 48 , at 233 ("There are two reasons for using the LSAT in law school admissions: it is the best single predictor of first-year performance, and it can be used to compare English speaking students from any point on the globe.").

50. Id. at 244 .

51. TAMANAHA, supra note 48 , at 96-99.

52. 2015 State of Legal Education: An In-Depth Look into Law School Admissions Choices, L. SCH. TRANSPARENCY, http://lawschooltransparency.com /reform/projects/investigations/2015/ (last visited Mar. 16, 2016).

53. Id.

54. aBa Standards and Rules of Procedure for Approval of Law Sch. 2015-2016, Standard 501(b) (AM. BAR ASS'N 2015).

55. See, e.g., Grant Wiggins \& JAY MCTighe, Understanding BY DESigN (2005); Michael Kerchner et al., Identifying and Using 'Core Competencies' to Help Design and Assess Undergraduate Neuroscience Curricula, $11 \mathrm{~J}$. UNDERGRADUATE NEUROSCIENCE EDUC. A27 (2012). 
of a program before choosing courses, materials, or pedagogies. Neither tradition nor intuition drives intentional education; instead, educators tailor coursework to carefully articulated goals. ${ }^{56}$

Legal education relies heavily on the traditional wisdom that intentional educators eschew. Rather than assessing the legal needs of contemporary clients, the skills required to fill those needs, and the pedagogies that best build those skills, law schools rely on curricula and pedagogies that date back to the nineteenth century. Even when schools innovate, they rarely assess the impact of those innovations. As a result, we have few guideposts for measuring the success of our programs-or for improving them.

Several legal educators have called for a more intentional approach to curriculum design and pedagogic choices in legal education. ${ }^{57}$ By following that call, law schools can further their professional obligation to educate new members of the legal community.

\section{Serve Client and Community Needs}

As the educational arm of the legal profession, law schools have a duty to educate lawyers who will serve the needs of clients and their communities. A professionally responsible law school curriculum cannot merely teach the law and skills that professors want to teach; it must teach the law and skills that the community needs.

Our traditional law school curriculum focuses overwhelmingly on appellate advocacy. Students read appellate cases in most of their courses, write briefs in legal writing classes, and compete in an ever expanding number of appellate moot court competitions. This focus persists despite the fact that very few clients need appellate representation. Instead, those clients seek legal assistance for transactions, compliance, trial-level disputes, and other types of legal matters.

The study of appellate opinions and advocacy helps students hone their ability to analyze legal precedents. That ability, however, constitutes just one facet of law practice. For real life clients, facts matter as much as law-and personal goals matter more than policy considerations. The practicing lawyer has to juggle all of these considerations simultaneously while also coping with substantial uncertainty and change. Legal education's myopic focus on appellate opinions does not prepare students for the realities of a professional world in which the facts are not given, the parties' interests are ill-defined, and the client seeks to resolve a personal

56. See Wiggins \& McTighe, supra note 55, at 13.

57. See, e.g., Michael J. Madison, Preparing for Service: A Template for 21st Century Legal Education 5 (Univ. Pittsburgh Sch. Law, Working Paper No. 2015•27, 2015), http://papers.ssrn.com/sol3/papers.cfm?abstract_id=2646931. 
problem expeditiously rather than attempting to change legal precedent.

Law schools have started to refocus their curricula to recognize client needs, but there is much more work to be done. One of the first steps I would take is to develop high quality workshops that will teach tenured faculty the theory and practice of client representation. Tenured faculty disdain this work partly because they do not understand it. If we can teach faculty about client representation, including the theory that informs different aspects of that work, we might help them integrate client-service perspectives into their teaching. At the very least, we might make them more sympathetic toward the need for client-focused courses taught by other members of the faculty.

Those "other members of the faculty" should enjoy the same status and pay as professors who teach primarily appellate doctrine. Our caste system, which distinguishes tenured faculty from clinical or writing professors, harms the latter professors and perpetuates a false dichotomy in legal education. Most important, this discrimination impairs our profession's commitment to educate new lawyers. We cannot educate lawyers to serve clients effectively if we demean the professors providing essential components of that education. ${ }^{58}$

\section{Inspire Students to Serve Low-and Middle-Income Clients}

The fourth step in reshaping legal education is to inspire students to serve the low- and middle-income clients that our profession is failing. Today we graduate more than enough students to satisfy the legal needs of corporations, law firms, government agencies, and nonprofits. Low- and moderate-income individuals, on the other hand, are desperate for legal help. ${ }^{59}$ One aspect of this legal-service gap is economic, which I will address in a moment. Another part, however, stems from the status hierarchy within our profession.

58. For further discussion of this issue, see, for example, Mary Beth Beazley, "Riddikulus!": Tenure-Track Legal-Writing Faculty and the Boggart in the Wardrobe, 7 SCRIBES J. LEgal WRITING 79, 85-86 (2000); Catherine Martin Christopher, Putting Legal Writing on the Tenure Track: One School's Experience, 31 Colum. J. GeNDER \& L. 65, 68 (2015); Harold Anthony Lloyd, Exercising Common Sense, Exorcising Langdell: The Inseparability of Legal Theory, Practice, and the Humanities, 49 WAKE FonEST L. REV. 1213, 1244-45 (2014).

59. See, e.g., Ronald S. Flagg, Access to Civil Justice: Keeping America's Promise, 24 KAN. J.L. \& PUB. PoL'Y 571 (2015); Gillian K. Hadfield, The Cost of Law: Promoting Access to Justice Through the (Un)corporate Practice of Law, 38 InT'L Rev. L. \& ECON. 43 (2014); Richard W. Painter, Pro Se Litigation in Time of Financial Hardship - A Legal Crisis and Its Solutions, 45 FAM. L.Q. 45 (2011); Deborah L. Rhode, Access to Justice: A Roadmap for Reform, 41 FORDHAM URB. L.J. 1227 (2014). 
Repeated studies confirm a strong status hierarchy among lawyers. 60 Judges and corporate attorneys are at the top. Government and public interest lawyers are in the middle. Lawyers who represent low- and middle-income clients in private practice are at the bottom. The latter are lawyers who handle personal injury claims, small-asset divorces, personal bankruptcies, home foreclosures, social security claims, workers' compensation suits, and immigration defense. These lawyers receive neither the high pay of corporate lawyers nor the professional appreciation awarded government and public interest attorneys. As private practitioners, they do not even qualify for loan forgiveness-even when they earn less than Legal Aid lawyers. ${ }^{61}$

If we want to close the justice gap, assuring that low- and middle-income clients receive adequate legal services, we need to overcome this hierarchy. Law schools, which lay the foundation for professional attitudes, must elevate the status of solo and small-firm lawyers who offer essential legal services to low- and middle-income clients. I can imagine many ways to achieve that goal. We could hire more professors who have served those clients. We could offer more courses that prepare students for this practice. We could target scholarship money to students committed to serving underrepresented clients through private practice. We could broaden our concept of "public service" work. ${ }^{62}$ We could fund loan forgiveness for all graduates who earn low salaries while serving low- and moderate-income clients. ${ }^{63}$ We could create incubators for graduates starting their own practices, and we could organize networks of alumni practicing in these areas. ${ }^{64}$

60. See, e.g., John P. Heinz et al., Urban Lawyers: The New Social STRUCTURE OF THE BAR (2005) (examining the "extremes of the hierarchies that separate lawyers"); JOHN P. HEINZ \& EDWARD O. LAUMANN, CHICAGO LAWYERS: THE SOCIAL STRUCTURE OF THE BAR (1982) (discussing the types of lawyers that are "clearly identifiable" throughout the legal profession).

61. Jonathan D. Glater, Student Debt and Higher Education Risk, 103 CALIF. L. REV. 1561, 1605-06 (2015).

62. See, e.g., Susan D. Carle, Re-Valuing Lawyering for Middle-Income Clients, 70 FoRDHAM L. REV. 719 (2001).

63. A few elite law schools include low-earning private practitioners in their loan forgiveness programs. See COAP Highlights \& FAQs, YALE L. SCH., https://www.law.yale.edu/admissions/cost-financial-aid/post-graduate-loan -repayment/coap-highlights-faqs (last visited Mar. 16, 2016) (describing Yale Law School's Career Options Assistance Program); Low Income Protection Plan, HARVARD L. Sch., http://hls.harvard.edu/dept/sfs/lipp/ (last visited Mar. 16, 2016). Unfortunately, such extensive programs probably would not be financially feasible at most law schools.

64. During the last five years, several law schools have developed incubators of this nature. See, e.g., Laura Dym Cohen et al., Launching the Los Angeles Incubator Consortium, 83 UMKC L. REV. 861 (2015); Tammy M. Kudialis, A Proposed Model for Creating a Law School Based Solo or Small Firm Incubator Program, 83 UMKC L. REV. 823 (2015); Cory H. Morris, Access 
Some schools have taken worthwhile steps in this direction, but we need to address this goal much more explicitly. To fulfill our promise of "justice for all," law schools must inspire students to enthusiastically counsel clients about personal injuries, divorces, foreclosures, social security, workers' compensation, immigration, and the other legal issues that low- and moderate-income individuals face.

\section{E. Teach Students How to Deliver Legal Services Efficiently}

Inspiration, of course, will not be sufficient to serve the needs of low- and moderate-income clients. Law schools must also teach students how to deliver legal services more efficiently so clients can afford their legal counsel. As professionals, lawyers control both the content and delivery of their services. Law schools eagerly teach students content but rarely discuss delivery. Practitioners have been slow to develop new methods of delivering legal services. Without effective delivery methods, clients have suffered.

Innovation, however, has finally touched the delivery of legal services. Online companies have created legal documents for millions of customers. ${ }^{65}$ Those companies also allow customers to obtain answers to simple legal questions quickly and cheaply. ${ }^{66}$ Innovative law firms have traded brick-and-mortar offices for virtual platforms that deliver services at reduced prices and greater convenience.67 Even conventional law firms, government offices, and nonprofits have adopted practices that streamline the delivery

to Justice, Observations and Thoughts from the Incubator-A New York State of Mind, 83 UMKC L. REV. 883 (2015).

65. See Anthony Ha, LegalZoom Files for \$120M IPO, Saw $\$ 156 M$ in Revenue Last Year, TECHCRUNCH (May 11, 2012), http://techcrunch.com/2012 105/11/legalzoom-ipo/ (reporting that LegalZoom had served two million customers by 2012); Rocket LawyerTM Raises $\$ 18.5$ Million to Fund Rapidly Growing Online Legal Service, Rocket LAW. (Aug. 11, 2011), https://www.rocketlawyer.com/news/article-Series-D-Funding.aspx ("Over 15 million small businesses and consumers have used Rocket Lawyer's easy, webbased do it yourself tools and legal plans.").

66. See Ask a Lawyer, Avvo, http://www.avvo.com/ask-a-lawyer (last visited Mar. 16, 2016) (allowing users to obtain online answers from attorneys for free, or to speak with an attorney by phone for thirty-nine dollars); JustAnswer Legal, JUSTANSWER, http://www.justanswer.com/law/\# (last visited Mar. 16, 2016) (allowing users to obtain quick answers to legal questions for a small fee); Legal Advice in Minutes, ROCKET LAw., https://www.rocketlawyer.com/ask -a-lawyer.rl (last visited Mar. 16, 2016) (allowing users to post short legal questions and receive responses from online attorneys, without charge).

67. See, e.g., Stephanie L. Kimbro, VirTual LaW Practice: How to Deliver LeGal Services OnLINe (2d ed. 2015); Timothy J. Clewell, Note, The AttorneyClient Relationship in the Digital Age, 28 GEO. J. LEGAL ETHICS 451, 451 (2015); About VLP, VLP L. GROUP, http://www.vlplawgroup.com/About.aspx (last visited Mar. 16, 2016) (extolling the group's "low-overhead environment" and use of cloud services). 
of routine legal services-these changes reduce costs and expand access to legal services. ${ }^{68}$

Legal educators must keep pace with these developments. In fact, we should work actively with practitioners to develop still better ways of delivering legal services. Those delivery systems are as important today as the content we deliver. Every type of client, from a low-income individual to the largest corporation, is seeking lower-cost, more efficient legal services. Academic researchers can help practitioners identify delivery methods that meet those goals without compromising quality. We can also teach students the value of new delivery systems, how to use those systems, and how to continue improving their service to clients.

\section{F. Develop Transferrable Approaches to Learning}

The final task for law schools to tackle today is the development of pedagogies that promote lifelong learning in the workplace. The teaching methods we use in the classroom create a powerful template for how graduates will learn-and teach others-in the workplace. Our stress on the Socratic method, for example, suggests that this is the most effective way to learn law. Our parsimonious feedback, similarly, signals that lawyers should be able to learn on their own, without input from more senior practitioners.

Like other contributors to this Symposium, I question the effectiveness of these methods on campus. Whatever their value in law school classrooms, however, these methods are deadly in the workplace. Senior lawyers sometimes try to "educate" junior ones by firing questions at them, exposing their ignorance to peers, and rejecting work with no feedback other than "this won't cut it!" This behavior should not surprise any of us; the senior lawyers are simply replaying the educational scripts we gave them in law school. Few, however, believe that this is an effective way to promote workplace growth.

What else do our law school pedagogies teach lawyers about learning? Most of our classes suggest that learning is both competitive and isolated. We may encourage students to form study groups, but we test and grade them individually. We also tell students that they should learn primarily from assigned cases, eschewing reliance on study aids or other secondary sources. We

68. Richard Susskind reflected on these changes in his provocatively titled book The End of Lawyers? Rethinking the Nature of Legal Services, which explores the distinction between "bespoke" legal services and "commoditized" ones-as well as the inevitable path from one to the other. RICHARD SUSSKIND, THE END of LaWYers? ReTHINKING THE NATURE OF LEGAL SERVICES 28-32 (rev. ed. 2010). For a more recent discussion recognizing the value of both customized and commoditized services, see Alan R. Olson, A New Level of Strategic Planning: Managing Your Portfolio of Practices, OF Counsel, Feb. 2014 , at 8. 
certainly do not want them consulting the Internet for help! Yet study aids, secondary sources, and the Internet provide essential platforms for exploring new areas of law in practice.

We need to improve our pedagogy-not only to deliver the most effective education during law school, but also to help graduates transition to effective workplace learning and mentoring. We already know that law school cannot prepare graduates for a full career of law practice. We owe those graduates, accordingly, the best tools we can provide for extending their own learning and teaching the lawyers who follow them.

\section{CONCLUSION}

Education lies at the heart of every profession. Professionals must learn the specialized knowledge, skills, and decision-making strategies of their field, and they must continuously hone their expertise. To assure continued service to clients and society, professionals also commit to sharing their expertise with new members of their community. The promise embedded in the Hippocratic oath, "[t]hat just as I have learned from those who preceded me, so will I instruct those who follow me in the science and art of medicine,"69 applies to all professions. Lawyers have been slow to recognize the power of this promise, but it is one that can strengthen both the profession and its clients. In this area, at least, Hippocrates has much to offer Socrates.

69. Edelstein, supra note 1 , at 3. 